\title{
ANALISIS HUBUNGAN WAKTU TUNGGU TERHADAP KEPUASAN PASIEN PADA PUSKESMAS MACCINI SOMBALA
}

\author{
1|Dedi Maulana, 2|Risma Tamrin, 3|Andi Alim, 4|Ali Imran \\ Email Korespondensi: dedimaulana8489@gmail.com \\ Fakultas Kesehatan Masyarakat, Universitas Pejuang Republik Indonesia, Indonesia
}

\begin{abstract}
Waiting time for services is a problem that often causes patient complaints in several health agencies. The length of time a patient waits at registration, examination, and reception drugs are reflects how the agencies manages the service component that is tailored to the patient's situation and expectations. This study aims to see the relationship between waiting time and patient satisfaction. This study uses an analytic observational research design with a cross-sectional study approach conducted at Public Health Center, Maccini Sombala of Makassar City. The sampling technique used purposive sampling with a total of 170 respondents. Analysis test with chi square test with significance level $p<0.05$. From the results of the chi square test waiting time for registration and examination of the drug to patient satisfaction, the $p$ value $=0.000$ and $0.021<0.05$ means Ho is rejected and Ha is accepted, meaning that there is a relationship between waiting time registration and examination with patient satisfaction. While the time of receiving drugs with patient satisfaction is obtained $p=0.400>0.05$ means that Ho is accepted and Ha is rejected, meaning there is no relationship between waiting time of taking drugs with patient satisfaction. So, it is recommended to health workers to be more committed and disciplined in providing services in accordance with the schedule that has been set.
\end{abstract}

\begin{abstract}
Abstrak
Waktu tunggu pelayanan merupakan masalah yang sering menimbulkan keluhan pasien dibeberapa instansi kesehatan. Lamanya waktu tunggu pasien di pendaftaran, pemeriksaan, pengambilan obat mencerminkan bagaimana instansi tersebut mengelola komponen pelayanan yang disesuaikan dengan situasi dan harapan pasien. Penelitian ini bertujuan untuk melihat hubungan waktu tunggu dengan kepuasan pasien. Penelitian ini menggunakan desain penelitian observasional analitik dengan pendekatan studi Cross- sectional yang dilakukan di Puskesmas Maccini Sombala Kota Makassar. Teknik pengambilan sampel menggunakan purposive sampling dengan jumlah responden sebanyak 170 responden. Uji analasis dengan uji chi square dengan tingkat kemaknaan $\mathrm{p}<0.05$. Dari hasil uji chi square waktu tunggu pendaftaran dan pemeriksaa obat terhadap kepuasan pasien didapatkan nilai $\mathrm{p}=0.000$ dan $0.021<0.05$ berarti Ho ditolak dan Ha diterima artinya ada hubungan antara waktu tunggu pendaftran dan pemeriksaan dengan kepuasan pasien. Sedangkan waktu pengambilan obat terhadap kepuasan pasien di dapatkan nilai $\mathrm{p}=0.400>0.05$ berarti Ho diterima dan Ha di tolak artinya tidak ada hubungan antara waktu tunggu pengambilan obat dengan kepuasan pasien. Sehingga, disarankan kepada petugas kesehatan agar lebih komitmen dan disiplin waktu dalam memberikan Pelayanan yang sesuai dengan jadwal yang telah ditetapkan.
\end{abstract}

Kata Kunci: Waktu Tunggu Pendaftaran; Pemeriksaan; Pengambilan Obat; Kepuasan

\section{PENDAHULUAN}

Waktu tunggu adalah lamanya waktu pasien menunggu pelayanan kesehatan sampai mendapat resep dari dokter, menunggu dalam waktu yang lama menyebabkan ketidakpuasan pasien/pelanggan Erhun, 2003 dalam Hasan (1). Tiga penyebab utama lamanya waktu pelayanan pasien yaitu: lamanya waktu pendaftaran diloket, terbatasnya jumlah dokter, pasien yang banyak, terbatasnya staf pelayanan 
kesehatan lainnya (2). Waktu tunggu di rawat jalan kurang dari 60 menit, kepuasan pelanggan/pasien di atas $90 \%(3)$.

Puskesmas merupakan Unit Pelaksana Teknis Daerah (UPTD) dinas kesehatan kabupaten/kota, sehingga dalam melaksanakan tugas dan fungsinya, akan mengacu pada kebijakan pembangunan kesehatan pemerintah daerah kabupaten/kota bersangkutan yang tercantum dalam Rencana Pembangunan Jangka Menengah Daerah (RPJMD) dan Rencana Lima Tahunan dinas kesehatan kabupaten/kota (4).

Berdasarkan hasil survei kepuasan pasien rawat jalan di Puskesmas Pandanaran Semarang tahun 2005 menyimpulkan bahwa terdapat 50\% orang menyatakan tidak puas terhadap pelayanan rawat jalan disebabkan karena 30\% orang menyatakan waktu tunggu pasien yang lama. Hasil penelitian Wahono 2011 menyimpulkan bahwa terdapat hubungan yang kuat antara lama waktu tunggu dengan kepuasan pasien $(\mathrm{p}<0,05)$ di Instalasi Rawat Jalan RSJ Provinsi Kalimantan Barat (5).

Waktu tunggu merupakan masalah yang sering menimbulkan keluhan dari pasien di beberapa fasilitas kesehatan. Hart dalam Oroh menyatakan bahwa, pasien sangat memperhatikan waktu tunggu pelayanan. Waktu tunggu yang panjang secara konsisten dapat menyebabkan ketidak puasan dari pasien. Lama waktu tunggu memberikan pengaruh yang besar kepada pasien terhadap tingkat kepuasan mereka karena berhubungan dengan mutu pelayanan atau pengobatan sehingga harus diperhatikan oleh penentu kebijakan (6).

Pusat Kesehatan Masyarakat (Puskesmas) sebagai penyelenggara upaya kesehatan tingkat pertama memiliki tanggung jawab dalam memberikan pelayanan kesehatan kepada seluruh masyarakat yang secara administratif berdomisili di wilayah kerjanya. Dengan adanya Puskesmas diharapkan masyarakat dapat memperoleh pelayanan kesehatan bermutu dengan akses termudah dan biaya yang terjangkau (7).

Waktu tunggu merupakan hal yang sensitif, dalam arti waktu tunggu berisiko menyebabkan mutu pelayanan kesehatan disebuah Puskesmas menurun. Karena pada saat pasien menungggu, pasien selalu mendapatkan kondisi dimana ruangan tunggu yang sempit, kursi yang disediakan tidak cukup dengan jumlah pasien yang datang, antrian yang lama saat pendaftaran di karenakan banyaknnya pasien yang datang berkunjung. Pada saat pemeriksaan pasien harus menunggu di poli karena ada 1 dokter umum dan 1 dokter gigi sedangkan pasien yang datang perhari 50-100 orang. Dan pasien harus menunggu lagi karena setelah menyerahkan resep obat petugas apotek harus memeriksa resep terlebih dahulu dan menyediakan obat berdasarkan peraturan perundang undang yang berlaku sehingga membuat waktu tunggu yang lama. Waktu tunggu obat juga sangat berpengaruh terhadap kepuasan pasien. Akibat waktu tunggu yang tidak efisien tersebut dapat megundang ketidakpuasan pasien akan sebuah pelayanan kesehatan.

Seiring dengan meningkatnya tingkat pendidikan dan tingkat sosial-ekonomi masyarakat, maka tuntutan terhadap pelayanan kesehatan juga semakin meningkat. Jumlah sarana pelayanan kesehatan telah memperketat persaingan antara sarana pelayanan kesehatan baik milik pemerintah maupun swasta. Persaingan yang terjadi 
tidak hanya dari sisi teknologi pemeriksaan, akan tetapi persaingan yang lebih berat yaitu persaingan dalam pelayanan kesehatan yang berkualitas Ahmed, 2011 dalam Mayasari (8). Institusi kesehatan harus memperhatikan kualitas pelayanannya termasuk waktu tunggu pasien karena dapat berpengaruh terhadap tingakat kepuasan pasien.

Waktu tunggu di Indonesia ditetapkan oleh Departemen Kesehatan melalui standar pelayanan minimal. Setiap Puskesmas harus mengikuti standar pelayanan minimal tentang waktu tunggu ini. Kategori jarak antara waktu tunggu dan waktu periksa yang diperkirakan bisa memuaskan atau kurang memuaskan pasien antara lain yaitu saat pasien datang mulai dari mendaftar ke loket, antri dan menunggu panggilan ke poli untuk dianamnesis dan diperiksa oleh dokter, perawat atau bidan lebih dari 90 menit (kategori lama), 30 - 60 menit (kategori sedang) dan $\leq 30$ menit (kategori cepat). Waktu tunggu di Indonesia ditetapkan oleh Kementrian Kesehatan melalui standar pelayanan minimal. Pelayanan minimal di rawat jalan berdasar Kemenkes Nomor 129/Menkes/SK/II/2008 ialah kurang atau sama dengan 60 menit, Kemenkes, 2008 dalam Nugraheni (9).

Menurut Meutia Dewi kepuasan pasien adalah suatu keadaan yang dirasakan pasien setelah ia mengalami suatu tindakan atau hasil memenuhi harapannya (10). Sedangkan menurut Pohan 2006 dalam Handayani kepuasan pasien adalah suatu tingkat perasaan pasien yang timbul sebagai akibat dari kinerja layanan kesehatan yang diperolehnya setelah pasien membandingkannya dengan apa yang diharapkannya (11).

Puskesmas Maccini Sombala merupakan salah satu Puskesmas yang ada di Kecamatan Tamalate Kota Makassar. Puskesmas ini memiliki ruang lingkup yang masyarakatnya sangat padat jadi mempengaruhi jumlah kunjungan pasien di Puskesmas Maccini Sombala. Menurut pegawai di Puskesmas Maccini Sombala data kepesertaan selalu bertambah setiap bulannya karena dilihat dari penduduk yang sangat padat.

Berdasarkan data rekapan kunjungan pasien di Puskesmas Maccini Sombala, pada bulan Oktober 2018 total kunjungan pasien 1267 kunjungan berulang 707 menurun pada bulan November total kunjungan pasien 1187 kunjungan berulang 679 dan menurun lagi pada bulan Desember total kunjungan 936 kunjungan berulang 510. Kunjungan pasien tercatat mengalami penurunan pada setiap bulannya dilihat dari 3 bulan terakhir dengan total kunjungan dari bulan Oktober hingga bulan Desember adalah 3390 pasien. Terlihat dari jumlah kunjungan pasien yang banyak maka akan mempengaruhi waktu tunggu. Oleh karena itu saya tertarik untuk meneliti apakah terdapat hubungan waktu tunggu dengan kepuasan pasien.

\section{METODOLOGI PENELITIAN}

Desain penelitian ini menggunakan analitik observasional dengan pendekatan studi Cross-sectional (studi potong lintang) yaitu penelitian hanya melakukan observasi dan pengukuran variabel pada satu saat tertentu saja. Kata satu saat bukan berarti semua subyek diamati tepat pada satu saat yang sama, tetapi artinya tiap subyek hanya diobservasi satu kali dan pengukuran variabel subyek dilakukan pada saat pemeriksaan tersebut. Penelitian analitik observasional adalah penelitian yang 
berupaya mencari hubungan antara variabel, pada penelitian ini dilakukan analisis terhadap data yang telah terkumpul(1).

Populasi pada penelitian ini adalah Pasien yang berkunjung di Puskesmas Maccini Sombala, jumlah populasi 510 adalah jumlah kunjungan berulang yang datang di Puskesmas Maccini Sombala dalam satu bulan terakhir (Desember 2018). Sedangkan, Sampel yaitu sebagian pasien yang kunjungan berulang di Puskesmas Maccini Sombala sebanyak 170 orang.

Cara Pengambilan Sampel dilakukan dengan cara purposive sampling yakni pengambilan sampel berdasarkan kriteri pasien di Puskesmas Maccini Sombala Kota Makassar. Pasien berulang yang berkunjung di Puskesmas Maccini Sombala dan Pasien yang berumur 20-50 Tahun. Penentuan jumlah sampel dilakukan berdasarkan pengembangan rumus yang ditemukan oleh Issac dan Newton tahun 1976 (12).

Cara Pengumpulan data primer diperoleh secara langsung dari responden dengan menggunakan instrumen pengisian kuisioner dengan pertanyaan terpimpin untuk mengukur waktu tunggu pendaftaran, pemeriksaan, pengambilan obat dan kepuasan pasien. Sedangkan Data sekunder diperoleh secara langsung dari Puskesmas Maccini Sombala. Cara pengolahan data dengan cara editing, coding, tabulasi data dengan menganlisa data univariat dan bivariat .

Analisis data univariat dilakukan terhadap tiap-tiap karakteristik responden dan variabel penelitian untuk melihat tampilan distribusi frekuensi presentase dari tiap-tiap karakteristik responden, variabel independent dan variabel dependent. Sedangkan Analisis Bivariat dilakukan untuk melihat hubungan antara variabel bebas dan variabel terikat. Dilakukan dengan pengujian hipotesis menggunakan uji statistik Chi Squera dan hipotesis yang akan diuji adalah hipotesis Null (Ho) dimana Ho di tolak jika $\mathrm{X}^{2}$ dihitung lebih besar dari $\mathrm{X}^{2}$ tabel atau nilai $\mathrm{p}=0.000<$ dari $\alpha=0.05$. Penyajian Data yang telah diolah dan disajikan dalam bentuk tabel distribusi frekuensi kemudian disertai narasi/penjelasan.

\section{HASIL PENELITIAN}

Penelitian ini dilaksanakan untuk mengetahui hubungan waktu tunggu terhadap kepuasan pasien di Puskesmas Maccini Sombala Kota Makassar Tahun 2019 yang dilaksanakan sejak bulan Juni sampai bulan Juli 2019 dengan hasil sebagai berikut: 


\section{Karakteristik Responden}

Tabel. 1 Distribusi Responden Berdasarkan Kelompok Umur, Jenis Kelamin, Pendidikan, Pekerjaan Di Puskesmas Maccini Sombala Tahun 2019. n=170

\begin{tabular}{lcc}
\hline \multicolumn{1}{c}{ Karakteristik Responden } & n & \% \\
\hline Umur (Tahun) & 46 & 27.1 \\
$20-30$ & 56 & 32.9 \\
$31-40$ & 41 & 24.1 \\
$41-50$ & 27 & 15.9 \\
$51-60$ & & \\
\hline Jenis Kelamin & 36 & 21.2 \\
Laki - laki & 134 & 78.8 \\
Perempuan & & \\
Pendidikan & 56 & 32.9 \\
SD & 52 & 30.6 \\
SMP & 55 & 32.4 \\
SMA & 2 & 1.2 \\
Akademik & 5 & 2.9 \\
Sarjana & & \\
Pekerjaan & 15 & 8.8 \\
Karyawan Swasta & 19 & 11.2 \\
Wiraswasta & 2 & 1.2 \\
PNS & 1 & 0.6 \\
TNI/POLRI & 133 & 78.2 \\
Lain - lain & &
\end{tabular}

Sumber: Data Primer, 2019

Tabel. 1 menunjukkan umur responden antara lain: umur 20 - 30 sebanyak 46 responden (27.1\%), 31 - 40 sebanyak 56 responden (32.9\%), 41-50 sebanyak 41 responden (24.1\%), 51 - 60 sebanyak 27 responden (15.9\%). Sedangkan, untuk jenis kelamin menunjukkan bahwa dari 170 Responden, Laki - laki yaitu sebanyak 36 responden (21.2\%) dan perempuan sebanyak 134 responden $(78.8 \%)$.

Tabel. 1 juga memperlihatkan pendidikan responden SD sebanyak 56 responden (32.9\%), SMP sebanyak 52 responden (30.9\%), SMA sebanyak 55 responden (32.4\%), Akademik sebanyak 2 responden (1.2 \%) dan Sarjana/S1 sebanyak 5 responden (2.9\%). Sedangan, untuk pekerjaan responden karyawan swasta sebanyak 15 responden (8.8\%), wiraswasta sebanyak 19 responden $(11.2$ $\%)$, PNS sebanyak 2 responden (1.2\%), TNI/POLRI sebanyak 1 responden $(0.6 \%)$, Lain - lain sebanyak 133 responden (78.2 \%). 


\section{Analisis Univariat}

Tabel. 2 Distribusi Responden Berdasarkan Waktu Tunggu Pendaftaran, Pemeriksaan, Pengambilan obat dan Kepuasan pasien di Puskesmas Maccini Sombala Tahun 2019. $n=170$

\begin{tabular}{lcc}
\hline Variabel Penelitian & $\mathbf{n}$ & $\mathbf{\%}$ \\
\hline Waktu tunggu pendaftaran & & \\
Lama & 84 & 49.4 \\
Tidak Lama & 86 & 50.6 \\
\hline Waktu Tunggu Pemeriksaan & & \\
Lama & 150 & 88.2 \\
Tidak Lama & 20 & 11.8 \\
\hline Waktu Tunggu Obat & $\mathrm{n}$ & $\%$ \\
Lama & 18 & 10.6 \\
Tidak Lama & 152 & 89.4 \\
\hline Kepuasan Pasien & $\mathrm{n}$ & $\%$ \\
Tidak Puas & 28 & 16,5 \\
Puas & 142 & 83,5 \\
\hline
\end{tabular}

Sumber: Data Primer, 2019

Tabel. 2 menunjukkan bahwa waktu tunggu pendafataran, yang mengatakan menunggu Lama sebanyak 84 responden (49.4\%), yang mengatakan menunggu tidak lama sebanyak 86 responden (50.6\%), Sedangkan, untuk waktu pemeriksaan di didaptkan yang menyatakan lama sebanyak 150 responden (88.2\%) dan yang menyatakan tidak lama sebanyak 20 (11.8\%).

Tabel, 2 juga di atas memperlihatkan hasil waktu tunggu pengambilan obat, yang mengatakan menunggu Tidak lama sebanyak 18 responden (10.6\%) dan yang mengatakan menungu Lama menunggu sebanyak 152 responden (89.4\%). Sedangkan, kepuasan pasien di dapatkan 28 responden (16,5\%) yang menyatakan tidak puas dan 142 responden (83,5\%) yang menyatakan puas atas pelayanan petugas kesehatan di puskesmas maccini sombala.

\section{Analisis Bivariat}

Tabel. 3 Distribusi Responden Berdasarkan Hubungan Waktu Tunggu Pendaftaran, Pemeriksaan dan Pengambilan Obat Terhadap Kepuasan Pasien di Puskesmas Maccini Sombala Tahun 2019. $n=170$

\begin{tabular}{|c|c|c|c|c|c|c|c|}
\hline \multirow{3}{*}{ Variabel Penelitian } & \multicolumn{4}{|c|}{ Kepuasan Pasien } & \multirow{2}{*}{\multicolumn{2}{|c|}{ Jumlah }} & \multirow{3}{*}{$\begin{array}{c}\text { Uji } \\
\text { Statistik }\end{array}$} \\
\hline & \multicolumn{2}{|c|}{ Tidak Puas } & \multicolumn{2}{|c|}{ Puas } & & & \\
\hline & $\mathbf{n}$ & $\%$ & $\mathbf{n}$ & $\%$ & $\mathbf{n}$ & $\%$ & \\
\hline \multicolumn{8}{|l|}{ Waktu Tunggu Pendaftaran } \\
\hline Lama & 24 & 28.6 & 60 & 71.4 & 84 & 100 & \multirow{2}{*}{$p=0.000$} \\
\hline Tidak Lama & 4 & 4.7 & 82 & 95.3 & 86 & 100 & \\
\hline \multicolumn{8}{|l|}{ Waktu Tunggu Pemeriksaan } \\
\hline Lama & 28 & 18.7 & 122 & 81.3 & 150 & 100 & \multirow{2}{*}{$\mathrm{p}=0.021$} \\
\hline Tidak Lama & 0 & 0 & 20 & 100 & 20 & 100 & \\
\hline
\end{tabular}




\begin{tabular}{lccccccc}
\hline Waktu Tunggu Obat & & & & & & & \\
Lama & 2 & 11,1 & 16 & 88,9 & 18 & 100 & $\mathrm{p}=0.400$ \\
Tidak Lama & 26 & 17.1 & 126 & 82.9 & 152 & 100 & \\
\hline
\end{tabular}

Sumber: Data Primer, 2019

Tabel di atas menunjukkan bahwa hubungan waktu tunggu pendaftaran dengan kepuasan pasien di dapatkan dominan pasien merasa puas dengan waktu tunggu pendaftaran yaitu sektar 82 atau 95,3\%. Berdasarkan uji statistik, diperoleh nilai $P=$ Value $0,000<\alpha=0,05$ ini berarti bahwa Ho ditolak dan Ha diterima, sehingga ada hubungan yang bermakna antara waktu tunggu pendaftaran dengan kepuasan pasien.

Tabel di atas juga menunjukkan bahwa hubungan waktu tunggu pemeriksaan dengan kepuasan pasien di dapatkan dominan pasien merasa puas dengan waktu tunggu yaitu sektar 122 atau 81,3 \%. Berdasarkan uji statistik, diperoleh nilai $P=$ Value $0,021<\alpha=0,05$ ini berarti bahwa Ho ditolak dan Ha diterima, sehingga ada hubungan yang bermakna antara waktu tunggu pemeriksaan dengan kepuasan pasien.

Tabel. 3 juga memperlihatkan hasil hubungan waktu tunggu pengambilan obat dengan kepuasan pasien di dapatkan dominan pasien merasa puas dengan waktu tunggu pengambillan obat yaitu sekitar 126 atau 82,9\%. Berdasarkan uji statistik, diperoleh nilai $P=$ Value $0,400>\alpha=0,05$ ini berarti bahwa Ho diterimadan Ha ditolak, sehingga tidak ada hubungan yang bermakna antara waktu tunggu pengambilan obat dengan kepuasan pasien di Puskesmas Maccini Sombala Kota Makassar tahun 2019.

\section{PEMBAHASAN}

\section{Hubungan Waktu Tunggu Pendaftaran/Loket dengan Kepuasan Pasien}

Waktu tunggu merupakan masalah yang sering menimbulkan keluhan pasien di beberapa instansi kesehatan. Lama waktu tunggu pasien mencerminkan bagaimana Puskesmas mengelola komponen yang disesuaikan dengan situasi dan harapan pasien(2). Waktu tunggu pendaftaran yang lama disebabkan karena terjadinya antrian yang panjang. Antrian timbul disebabkan oleh kebutuhan akan layanan melebihi kemampuan (kapasitas) pelayanan atau fasilitas layanan, sehingga pengguna fasilitas yang datang tidak bisa segera mendapat layanan disebabkan kesibukan layanan, Antrian sering terjadi karena ketersediaan petugas pada bagian pendaftaran kurang dan waktu antar kedatangan pasien lebih cepat daripada waktu pelayanan.

Dari hasil penelitian, Pasien yang cepat datang biasanya menunggu lebih lama untuk mengambil nomor antrian karena petugas pendaftaran belum datang sedangkan pendaftaran buka jam 8.30, sehingga pasien yang datang jam $8.00-9.00$ tidak perlu menunggu untuk mengambil nomor antrian karena petugas sudah datang, pasien yang datang bisa langsung ambil nomor antrian dan menunggu panggilan ke loket pendaftaran dan pasien yang datang $>9.00$ biasa menunggunya sebentar atau lama untuk di panggil ke loket pendaftaran tergantung banyaknya pasien dengan waktu antrian, kalau banyak pasien pasti antrinya lama. Tetapi biasanya pada hari senin, selasa dan kamis pasiennya banyak jadi pasti antrinya juga lama. Berbeda di 
hari jumat dan sabtu biasanya pasien yang datang hanya sebanyak 30 orang lebih sedikit dibanding dengan hari - hari yang lain.

Kedatangan petugas pendaftaran juga mempengaruhi waktu tunggu pasien karena apa bila petugas lama maka waktu tunggu pasien juga akan semakin lama. Tetapi berbeda dengan petugas di Puskesmas Maccini Sombala, Petugas pendaftaran cepat datang hanya saja petugas kalau datang harus membersihkan ruangan terlebih dahulu sebelum melayani pasien dikarenakan puskesmas tidak memiliki petugas kebersihan, sehingga mempengaruhi waktu tunggu pasien. Berdasarkan SOP Puskesmas Macini Sombala pelayanan di mulai pada jam 08.00, Sedangkan responden yang mengatakan petugas belum ada saat menunggu pendaftaran di karenakan pasien yang datangnya sebelum jam 8 padahal petugas Puskesmas rata rata datang jam 8.00 terkecuali di hari sabtu, petugas harus datang jam 7.30 dikarenakan harus mengikuti senam lansia serta melakukan kerja bakti di Puskesmas sehingga jam pelayanan pada hari sabtu dimulai pukul 9.00, pasien yang datang cepat di hari itu biasa menunggu lama untuk pelayanan.

Berdasarkan hasil penelitian, faktor penyebab lama waktu tunggu pendaftaran yaitu pasien tidak membawa kartu berobat dan pasien lupa membawa kartu identitas. Serta faktor lain penyebab lama waktu tunggu dikarenakan komputer error, jaringan off-line, dokumen rekam medis yang tidak ditemukan dalam rak filing, dan waktu tunggu pasien yang lama akan berpengaruh pada pasien berikutnya. Standar pelayanan publik di Puskesmas Maccini Sombala waktu pelayanan loket 3 - 5 menit sedangkan berdasarkan standar pelayanan minimal yang ditetapkan oleh Departemen Kesehatan waktu tunggu pendaftaran $\leq 10$ menit (13).

Hasil Penelitian juga menemukan responden yang mempunyai waktu tunggu lama dan mengatakan tidak puas dikarenakan lama waktu tunggu di loket besar atau sama dengan 30 menit, akan tetapi tergantung dari banyaknya pasien yang berkunjung di Puskesmas Macini Sombala. Berdasarkan hasil perhitungan Chi Square diperoleh sig $(0,000)<0,05$ maka Ho ditolak dan Ha diterima artinya waktu tunggu pendaftaran yang lama mempunyai hubungan yang signifikan dengan kepuasan pasien. Hasil penelitian ini sesuai dengan penelitian Wahono yang menyimpulkan bahwa terdapat hubungan yang kuat antara lama waktu tunggu dengan kepuasan pasien $(\mathrm{p}<0,05)$. Waktu tunggu pelayanan yang lama atau lambat, akan menurunkan tingkat kepuasan keluarga pasien (5). Penelitian lain yang sesuai adalah penelitian yang dilakukan oleh Aulia Utami Dewi, dkk di ruang tunggu pendaftaran sebuah Rumah Sakit di Kota Sukoharjo menemukan 41 responden dengan waktu tunggu pendaftaran cepat sebagian besar merasa puas dengan pelayanan. Hasil uji statistik didapatkan nilai uji chi square sebesar $\mathrm{p}=0,000(\mathrm{p}<0,05)$, yang berarti Ho ditolak, jadi ada hubungan yang signifikan antara waktu tunggu pendaftaran dengan kepuasan pasien (14).

Hasil penelitian juga menemukan responden yang menyatakan tidak lama tetapi tidak puas dikarenakan pasien merasa fasilitas di Puskesmas Maccini Sombala belum bagus karena tidak memiliki toilet khusus pasien hanya terdapat 1 (satu) toilet di UGD dan 1 (satu) di lantai atas itupun toilet khusus pegawai Puskesmas. Kepuasan pasien bukan hanya disebebkan dari sisi waktu tunggu akan tetapi juga berhubungan dengan ketersediaan prasarana umum bagi pasien. 
Hasil berbeda diperoleh dari penelitian Riniyastuti 2013 dikutip oleh Aulia Utami Dewi, dkk yang menyimpulkan bahwa ada hubungan antara perilaku petugas, mutu informasi dan fasilitas umum dengan kepuasan pasien di TPPRJ, namun ditemukan hasil tidak terdapat hubungan antara waktu antrian pendaftaran (waktu tunggu pendaftaran) dengan kepuasan pasien (14). Jadi penelitian ini tidak mendukung penelitian tersebut. Dalam penelitian yang dilakukan oleh Hasan menyimpulkan bahwa tidak terdapat hubungan antara waktu tunggu pendaftaran dengan tingkat kepuasan pasien rawat jalan (1).

\section{Hubungan Waktu Tunggu Pemeriksaan dengan Kepuasan Pasien}

Menurut Marno waktu pemeriksaan dapat diartikan sebagai waktu yang diperlukan oleh seorang responden untuk memeriksa sesuatu. Kategori jarak antara waktu tunggu dan waktu sentuh yang diperkirakan bisa memuaskan atau kurang memuaskan pasien antara lain saat pasien datang mulai dari mendaftar ke loket, antri dan menunggu panggilan ke poli umum untuk dianamnesa (diperiksa) oleh dokter (15).

Mayoritas permasalahan pasien berobat ke beberapa Puskesmas disebabkan lamanya waktu tunggu yang begitu lama sehingga pasien merasa jengkel dan bosan. Waktu tunggu pemeriksaan yang lama di Puskesmas disebabkan karena dokter yang datang cepat tetapi lama untuk memberikan pelayanan (pemeriksaan) kepada pasien. Sebelum masuk ke poli pasien terlebih dahulu diperiksa tekanan darah dan berat badan oleh perawat untuk ditulis di rekam medik pasien sebelum masuk ke poli untuk diperiksa oleh dokter. Sedangkan, Responden yang mengatakan tidak melalui pemeriksaan tekanan darah dan berat badan yang langsung di periksa oleh dokter dikarenakan telah memiliki hasil pemeriksaan laboratorium. Menurut responden mengatakan pelayanan dokter di Puskesmas Maccini Sombala baik karena dokter sangat ramah sama pasien dan selalu memberikan saran kepada pasien. Tetapi lama waktu tunggu pemeriksaan dapat membuat pasien merasa jengkel. Kejengkelan pasien ini dikarenakan perawat yang memeriksa pasien sebelum masuk ke poli biasa terlambat datang dan meninggalkan tempat pemeriksaan. Sehingga, pasien yang mempunyai giliran untuk diperiksa tidak tahu. Jadi terkadang pasien berdiri mengambil rekam mediknya dimeja tempat perawat.

Faktor lain penyebab waktu tunggu yang lama yaitu kurangnya petugas di Puskesmas sehingga mempengaruhi lamanya waktu tunggu pasien. Sedangkan waktu tunggu unit pelayanan (pemerisaan) berdasarkan Standar Pelayanan Publik di Puskesmas Maccini Sombala 5-10 menit dan Waktu tunggu pemeriksaan atau pelayanan poliklinik rawat jalan $<10$ menit (3). Berdasarkan hasil perhitungan uji Chi Square diperoleh $\mathrm{p}$ value $0,021<0,05$ yang artinya Ho ditolak dan Ha diterima yaitu ada kecenderungan cepatnya waktu tunggu pemeriksaan akan membuat pasien puas dengan pelayanan, atau lamanya waktu tunggu pemeriksaan akan membuat pasien tidak puas dengan pelayanan. Menurut sebagian pasien tidak jadi masalah dengan waktu tunggu pemeriksaan yang lama yang jelas petugas baik, dokter sangat ramah dan pasien cocok dengan cara pemeriksaan dokter yang bagus.

Hal ini didukung dengan hasil penelitian Muthiah dengan hasil uji statistik Spearman diperoleh nilai $r$ hitung sebesar 0,23 dengan nilai $r=0,02(p$ value $<0,05)$ yang berarti secara statistik mempunyai makna bahwa hubungan waktu tunggu 
pemeriksaan dengan tingkat kepuasan pasien di Poliklinik Kebidanan dan Kandungan RSUD Kota Surakarta menunjukan arah hubungan yang positif dengan tingkat hubungan yang rendah. Hasil penelitian ini menunjukkan adanya kecenderungan semakin cepat waktu tunggu pelayanan semakin meningkat kepuasan pasien (2).

Hasil penelitian ini didukung oleh penelitian Utami di sebuah Rumah Sakit di Kota Solo menemukan hasil bahwa $80 \%$ pasien sangat puas dengan waktu tunggu. Hasil perhitungan chi square diperoleh sig $(0,000)$ berarti $<0,01$ maka Ho ditolak dan Ha diterima artinya waktu tunggu pelayanan/pemeriksaan pasien rawat jalan mempunyai hubungan yang signifikan dengan kepuasan pasien rawat jalan (2).

Adhesia Esti $\mathrm{P}$ dalam penelitian yang berjudul Pengaruh Waktu Tunggu dan Waktu Sentuh Pasien terhadap Tingkat Kepuasan Pasien Poli Umum di Puskesmas Sukorame Kota Kediri didapatkan bahwa setelah dilakukan uji statistik regresi ordinal diperolehkan bahwa sig $=0,000$ pada tingkat kepercayaan $95 \%$. Dengan demikian didapatkan hasil nilai $p$-value $<\alpha$ yakni 0,000 $<0,05$ maka Ho ditolak. Hal ini berarti menunjukkan bahwa adanya pengaruh antara waktu tunggu dan waktu sentuh terhadap tingkat kepuasan pasien poli umum di Puskesmas Sukorame Kota Kediri (15).

\section{Waktu Tunggu Pengambilan Obat dengan Kepuasan Pasien}

Waktu tunggu obat adalah waktu tunggu yang pasien dapatkan setelah memberikan resep kepada tenaga farmasi hingga mendapatkan obat. Setelah dilakukan penelitian didapatkan permasalahan pasien yang mempunyai keluarga di Puskesmas yang cepat mendapatkan pelayanan obat. Sehingga, terjadi penumpukan resep pada petugas entri Instalasi Farmasi Puskesmas Maccini Sombala. Sejak pasien meletakkan resep hingga proses entri dilakukan, dibutuhkan waktu rata-rata 10 menit pada saat jam sibuk. Sedangkan, proses entri resep sendiri untuk satu resep rata-rata membutuhkan waktu 2 menit. Lamanya proses entri data disebabkan karena petugas entri juga membantu menyerahkan obat, mempersiapkan, dan melakukan pengemasan obat pada jam-jam sibuk. Selain itu petugas entri juga melakukan konfirmasi hasil telaah resep kepada staf medis rawat jalan (dokter), menjawab pertanyaan dan memberikan penjelasan kepada pasien yang mengambil obatnya.

Pada proses entri resep hanya persiapan terdapat kendala petugas belum hafal letak dapat dilakukan oleh staf senior, habis stok obat sehingga pasien harus menunggu atau diberikan surat pengantar ke kimia farmasi. Jadi waktu tunggu sesuai dengan standar waktu tunggu obat yang di tetapkan oleh Kepmenkes. Hasil uji chisquare menunjukkan bahwa nilai $p$ value 0,400 dimana artinya ada tidak ada pengaruh antara waktu tunggu pengambilan obat terhadap kepuasan pasien rawat jalan di Puskesmas Maccini Sombala.

Berbeda dengan hasil penelitian yang di lakukan oleh Ika Nurjanah, dkk dalam penelitiannya yang berjudul Hubungan Waktu Tunggu Pelayanan Resep dengan Kepuasan Pasien di Apotek Pelengkap Kimia Farma didapatkan adanya hubungan antara waktu tunggu pelayanan resep dengan kepuasan pasien. Pelayanan resep yang lama akan menurunkan tingkat kepuasan pasien dalam hal waktu tunggu pelayanan. 
Pelayanan resep yang cepat akan meningkatkan kepuasan pasien dalam hal waktu tunggu pelayanan (16).

Kepuasan pasien adalah tingkat perasaan pasien yang timbul sebagai akibat dari kinerja layanan kesehatan yang diperolehnya, setelah pasien membandingkan dengan apa yang diharapkannya. Pendapat lain dari Endang bahwa kepuasan pasien merupakan evaluasi atau penilaian setelah memakai suatu pelayanan, bahwa pelayanan yang dipilh setidak-tidaknya memenuhi atau melebihi harapan (17).

\section{KESIMPULAN}

Berdasarkan hasil dan pembahsan penelitian tentang kepuasan pasien terhadap waktu tunggu di Puskesmas Maccini Sombala Kota Makassar tahun 2019 maka dapat diperoleh kesimpulan terdapat hubungan yang signifikan antara waktu tunggu pendaftaran dengan kepuasan pasien dengan nilai $(\mathrm{p}=0.000)<0.05$, Terdapat hubungan antara waktu tunggu pemeriksaan dengan kepuasan pasien dengan nilai $(\mathrm{p}=0,021)<0,05$ dan tidak terdapat hubungan antara waktu tunggu obat dengan kepuasan pasien dengan nilai $(\mathrm{p}=0,400)>0,05$ pada Puskesmas Maccini Sombala

\section{SARAN}

1. Bagi Petugas Puskesmas Maccini Sombala, sebaiknya petugas lebih memperhatikan lamanya waktu tunggu dengan bekerja lebih cepat dan tepat sesuai SOP agar pasien senantiasa merasa puas, senang terhadap pelayanan yang sudah diberikan oleh petugas.

2. Sebaiknya petugas pada bagian pendaftaran, poli dan apotek harus lebih disiplin dalam memberikan pelayanan kepada pasien agar pasien tidak terlalu lama menunggu.

3. Diharapkan kepada Manajemen Puskesmas Maccini Sombala untuk tetap meningkatkan pelayanan kesehatan dan ketersediaan prasarana umum bagi pasien agar masyarakat yang berkunjung dan membutuhkan pelayanan kesehatan merasa puas. Dengan kepuasan yang didapatkan maka pasien yang sakit dan membutuhkan pelayanan kesehatan tidak merasa berat datang ke Puskesmas.

\section{DAFTAR PUSTAKA}

1. Hasan. Hubungan Waiting Times/Waktu Tunggu dengan Kepuasan Pasien di Poliklinik Mata pada Instalasi Rawat Jalan di RSUD Tarakan Propinsi Kalimantan Timur Tahun 2013. In Makassar: Program Studi Ilmu Keperawatan; Fakultas Kedokteran; Universitas Hasanuddin; 2014.

2. Pratiwi MR, Sani FN. Hubungan Waktu Tunggu Pelayanan Terhadap Tingkat Kepuasan Pasien di Poliklinik Kebidanan dan Kandungan RSUD Kota Surakarta. Profesi (Profesional Islam): Media Publikasi Penelitian. 2017;14(2):24-30.

3. Menteri Kesehatan Republik Indonesia. Tentang Standar Pelayanan Minimal Rumah Sakit. 129/Menkes/SK/II/2008 Indonesia; 2008.

4. Menteri Kesehatan Republik Indonesia. Pedoman Manajemen Puskesmas. Menteri Kesehatan Republik Indonesia, 44 Tahun 2016 Jakarta; 2016. 
5. Wahono BT. Kepuasan Keluarga Pasien Terhadap Waktu Tunggu Pelayanan Di Instalasi Rawat Jalan Rumah Sakit Jiwa Provinsi Kalimantan Barat. Jurnal Wiyata Penelitian Sains dan Kesehatan. 2011;4(2):165-72.

6. Oroh OS. Persepsi pasien terhadap mutu pelayanan uskesmas Kota Yogyakarta: Studi kasus di Puskesmas yang menerapkan sistem manajemen mutu ISO dan yang tidak menerapkan sistem manajemen mutu ISO. Universitas Gadjah Mada; 2006.

7. Tanan L, Indar, Darmawansyah. Analisis Tingkat Kepuasan Pasien di Puskesmas Bara Permai Kota Palopo. Jurnal Administrasi dan Kebijakan Kesehatan. 2013;2(03):15-21.

8. Mayasari F. Analisis Hubungan Waktu Pelayanan dan Faktor Total Quality Service Terhadap Kepuasan Pasien di Poliklinik Kebidanan dan Kandungan RSIA Anugerah Medical Centre Kota Metro Tahun 2015. Jurnal Administrasi Rumah Sakit Indonesia. 2016;2(3):214-30.

9. Nugraheni R. Gambaran Waktu Tunggu Pasien dan Mutu Pelayanan Rawat Jalan di Poli Umum UPTD Puskesmas Pesantren 1 Kota Kediri Tahun 2017. Jurnal Wiyata Penelitian Sains dan Kesehatan. 2018;4(2):165-72.

10. Dewi M. Pengaruh Kualitas Pelayanan terhadap Kepuasan Pasien Pengguna BPJS pada Rumah Sakit Rehabilitasi Medik Kabupaten Aceh Timur. Jurnal Manajemen dan Keuangan. 2016;5(2):535-44.

11. Handayani S. Tingkat Kepuasan Pasien Terhadap Pelayanan Kesehatan di Puskesmas Baturetno. Profesi (Profesional Islam): Media Publikasi Penelitian. 2016;14(1):42-8.

12. Sugiyono. Metode penelitian pendidikan:(pendekatan kuantitatif, kualitatif dan R \& D). Bandung: Alfabeta; 2008.

13. Menteri Kesehatan Republik Indonesia. Standar Pelayanan Minimal Bidang Kesehatan di Kabupaten/Kota. Jakarta: Departemen Kesehatan RI; 2008.

14. Dewi AU, Astuti R, Werdani KE. Hubungan Waktu Tunggu Pendaftaran Dengan Kepuasaan Pasien Di Tempat Pendaftaran Pasien Rawat Jalan (TPPRJ) RSUD Sukoharjo. Fakultas Ilmu Kesehatan, Universitas Muhammadiya Surakarta. 2015;

15. P AE, Puspitasari Y, Rusmawati A. Pengaruh waktu tunggu dan waktu sentuh pasien terhadap tingkat kepuasan pasien Poli Umum di Puskesmas Sukorame Kota Kediri. STIKes Surya Mitra Husada. 2012;3:1-8.

16. Nurjanah I, Maramis FRR, Engkeng S. Hubungan Antara Waktu Tunggu Pelayanan Resep dengan Kepuasan Pasien di Apotek Pelengkap Kimia Farma BLU Prof. Dr. RD Kandou Manado. PHARMACON Jurnal Ilmiah Farmasi. 2016;5(1):362-70. 
111 Jurnal Kesehatan Vol (12) No (2) Tahun (2019)

17. Mamik. Manajemen Mutu Pelayanan Kesehatan Dan Kebidanan. Zifatama; 2014. 